Andrzej Paweł Wejland

ORCID: https://orcid.org/0000-0003-2484-8586

\title{
Dom na wsi. Antropologiczna lektura palimpsestów etnicznych: zamieszkanie i zadomowienie
}

\author{
A house in the country. An anthropological reading of ethnic \\ palimpsests: habitation and a sense of settlement
}

\begin{abstract}
The author's reflections are carried out on three interconnected planes.

On the first plane, the author attempts to demonstrate that the metaphorical concept of a palimpsest, which in anthropology is almost paradigmatically referred to cities and their spaces, may just as successfully be applied to the countryside and to rural space. A house in the country, just as a house in a city, located in an ethnically marked space - a formerly-German house, for instance - may then be viewed as an ethnic palimpsest delineated by the complexity of history and the logic of culture.

At the second plane of his reflections, the author attempts to show that an anthropological reading of a house as an ethnic palimpsest is the reading (i.e. the search for and analysis) of particular combinations of trace-objects. This reading must, in addition, be twofold, penetrating deep into the layers of the palimpsest which came to overlap with the passage of time, and concurrently moving on its surface structures in search of involutions. This approach conforms with Sarah Dillon's conception of combining palimpsestic reading with palimpsestuous reading.

On the third plane, taking as his example two adjacent formerly-German houses in the village of Cekcyn in the Tuchola Forest and the histories of two families that have migrated there, the author shows the applicability of this method of reading in the analysis of two types of habitation: one that results in a failure to achieve a sense of settlement and one that produces the feeling of being successfully settled. His reading of ethnic palimpsests constituted by these countryside houses is based mainly on narratives of memory which reflect settlement processes that took place in the Tuchola Forest after the Second World War, that is - in the histories of these Polish families - the episode of their settling in houses that formerly belonged to German residents.
\end{abstract}

Key words: house in the country, Cekcyn, Tuchola Forest, ethnic palimpsest, anthropological reading of ethnic palimpsests, habitation and a sense of settlement, narratives of memory 
Swoje rozważania autor prowadzi w trzech przenikających się płaszczyznach.

W płaszczyźnie pierwszej autor próbuje pokazać, że metaforyczne pojęcie palimpsestu, odnoszone w antropologii - bez mała paradygmatycznie - do miasta i jego przestrzeni, może być z równym powodzeniem stosowane wobec wsi i przestrzeni wiejskiej. Dom na wsi, jak dom w mieście, ulokowany w przestrzeni nacechowanej etnicznie, na przykład dom poniemiecki, może być wówczas widziany jako - określony złożonością dziejów i kulturową logiką - palimpsest etniczny.

Dociekaniami w drugiej płaszczyźnie autor stara się dowieść, że antropologiczna lektura domu jako palimpsestu etnicznego polega na czytaniu (wypatrywaniu i analizie) szczególnych kombinacji śladów-rzeczy. Ma to być przy tym lektura podwójna: i wdzierająca się w głąb, czyli w nakładające się z biegiem czasu warstwy palimpsestu, i poruszająca się - w poszukiwaniu inwolucji - po jego strukturach powierzchniowych. Odpowiada to idei wiązania czytania palimpsestycznego z czytaniem palimpsestowym, przedstawionej przez Sarę Dillon.

W płaszczyźnie trzeciej, na przykładzie dwóch (stojących po sąsiedzku) domów poniemieckich we wsi Cekcyn w Borach Tucholskich i historii przybyłych tu dwóch rodzin polskich, autor ukazuje przydatność takiej lektury do diagnozy dwóch typów zamieszkania - tego, które zmierza do nieudanego zadomowienia, i tego, które w intencjach i działaniach prowadzi do zadomowienia udanego. Lekturę wiejskich domów-palimpsestów etnicznych autor opiera głównie na relacjach wspomnieniowych odtwarzających okres osiedlania się w Borach Tucholskich po II wojnie światowej, czyli - w historii owych polskich rodzin - epizod zamieszkania przez nie w domach poniemieckich.

Słowa kluczowe: dom na wsi, Cekcyn, Bory Tucholskie, palimpsest etniczny, antropologiczne czytanie palimpsestów, zamieszkanie i zadomowienie, relacje wspomnieniowe

Odebrano / Received: 31.01.2019

Zaakceptowano / Accepted: 27.08.2019

\section{Palimpsest. 0 przeniesieniu spojrzenia antropologicznego z miasta na wieś}

Wbrew każącemu grzęznąć w myślowej nieruchomości stereotypowi, sklejającemu pojęcie palimpsestu z refleksją nad miastem i badaniem miejskiej przestrzeni, warto podjąć wyzwanie przeniesienia pojęcia palimpsestu w dziedzinę rzadko przez nie nawiedzaną: do antropologicznych czy też w szerokim sensie humanistycznych rozważań poświęconych wsi i do mogących im towarzyszyć badań wiejskiej przestrzeni - tych terenowych, etnograficznych. O miastach-palimpsestach napisano u nas wiele świetnych rozpraw - o Gdańsku, Łodzi, Królewcu, Wilnie, Wałbrzychu, Krakowie, Płowdiw czy Stambule, o wsiach-palimpsestach większych rodzimych tekstów prawie brak. Nie tekstów, w których słowo „palimpsest” występuje jako termin ozdobny, lecz tekstów, w których odgrywa ono rolę konstruktu radykalnie organizującego i scalającego badawczą koncepcję i jej empiryczne ekstensje, na swój sposób więc „teoretycznego”.

1 Z idei palimpsestu potraktowanej na poważnie, czyli niepowierzchownie, korzystali więc na przykład piszący o miastach: o Gdańsku - Bagłajewski 1999; Weżgowiec 2013; Rogóż 2015; o Łodzi - Karpińska 
Czy ktoś, kto podejmie to wyzwanie, dokona - toutes proportions gardées - paradygmatycznego przewrotu? Zapewne nie, bo wypowie co najwyżej coś, co inni ,jakoś” znają - ,jakoś”, to znaczy na zasadzie wspólnotowej wiedzy ukrytej, niejawnej, milczącej, lecz - gdy zajdzie potrzeba - gotowej do przypomnienia. Zachęta do poszerzenia naszej antropologicznej i etnograficznej wyobraźni płynie wciąż przecież od starych, mądrych badaczy. Spójrzcie na wieś na pograniczu, powiedzieliby oni nawet karcąco, lub na wieś, która w swojej historii przechodziła z rąk do rąk, w której na przykład to, co polskie i to, co niemieckie utworzyło plastry etnicznego przekładańca, w której dotyk i ślady spotkania z etniczną innością na stałe utkwiły w tym, co materialne, i w tym, co niematerialne: w pamięci i opowieściach. Czy to nie „klasyczny” - taki jak w miastach - palimpsest?

\section{Pojęcie palimpsestu - idee konstytutywne}

Pojęcie palimpsestu, o które tu chodzi, to oczywiście pojęcie metaforyczne, nie zaś pojęcie użyte $\mathrm{w}$ jego pierwotnym, dosłownym sensie. Pojęcie metaforyczne nie musi, a nawet nie może być pojęciem „luźnym”, ani tym bardziej „mętnym”, znaczeniowo nieokreślonym bądź rozmazanym, rozlazłym. Dbając o ścisłość, powinno równocześnie uwrażliwiać: rozświetlać rozważania ogólne i podpowiadać tropy szczegółowe². Metaforyczne pojęcie palimpsestu - dobrze służące mojemu wyzwaniu - to figura myśli próbująca przede wszystkim zachować semantyczną analogię z pojęciem literalnym: podobieństwo formalnej struktury i kulturowej logiki.

Jeśli myśląc o mieście lub o wsi, o miejskiej bądź wiejskiej przestrzeni, o krajobrazie, o domu w mieście czy na wsi, dostrzeżemy w nich, odbijający zmiany w czasie, układ warstwowy, to będzie to oznaczać, że ich „wnętrze” podporządkowaliśmy idei osadzania się lub nakładania jednego na drugim - pokładu na pokładzie, słoja na słoju. To dla palimpsestu rozumianego metaforycznie podstawowa, ale nie jedyna idea konstytutywna i jeszcze - by tak rzec - niepełna. Strukturę antropologiczną, humanistyczną palimpsestu w pełni odsłonimy, zakładając, że w tworzenie warstw intencjonalnie, z rozmysłem wtrącił się człowiek.

To samo odnosi się również do drugiej idei konstytutywnej: zmywania warstw nieprzypadkowego usuwania i wymazywania, działania celowego, chcącego coś uczynić

2004a; Karpińska 2004b; Karpińska 2015; o Królewcu - Błażejewski 2007; Wójcik-Żołądek 2014; o Wilnie - Lul 2011; Kowerko-Urbańczyk 2013; Kasner 2017; o Wałbrzychu - Burzyńska 2013; Taranek-Wolańska 2013; o Krakowie - Czabanowska-Wróbel 2011 lub Czabanowska-Wróbel 2013; Golonka-Czajkowska 2017; o Płowdiw - Usakiewicz 2012; o Stambule - Kuchowicz, Wolak 2012. Bardziej ogólne, często również krytyczne rozważania dotyczące odnoszenia idei palimpsestu do miasta prowadziły natomiast między innymi: Rewers 2005; Rybicka 2011; Czermińska 2013; Szalewska 2017; Gomóła, Szawerna-Dyrszka 2018.

2 Pojęcie, które spełni te oczekiwania, powstać może, gdy przy jego definiowaniu połączy się dwie strategie konceptualne: strategię pojęciowej precyzji i strategię pojęciowego uwrażliwienia, por. Wejland 2013, s. 213-220. 
niewidocznym, niedostrzegalnym, a nawet nieobecnym, zdrapywania i ścierającej czystki. Podobnie jest z nakładaniem nowej warstwy po usunięciu starej, z przykrywaniem „tekstu” dawnego przez inny kulturowy „tekst”. Praktyka wymazywania i zasłaniania bywa regulowana społecznie - jest wówczas zwykle mechanizmem poddanym jakiejś ideologii „porzucania” lub „zapominania”, odrywania się (może i wybiórczo) od tego, co dawne i wtapiania zamiast niego czegoś choćby tylko innego - nie „obcego”, lecz „swojego".

Trzecia idea konstytutywna to idea prześwitywania. Wskazuje ona na „zasadniczą”, wynikającą choćby z działania czasu nieskuteczność wymazywania i zakrywania: palimpsest rozpada się w środku i na wierzchu, strzępi się i kruszy, coś jego formę mąci lub rujnuje. Prześwit ukazuje głębię i jednocześnie uczestniczy w kreacji powierzchni palimpsestu - odsłania to, co było niewidoczne (może schowane i ukryte, a przez to nieuchwytne dla kulturowego dyskursu), sugeruje istnienie czy też obecność w głębi palimpsestu „ducha” czasu, a na jego powierzchni „cienia” historii. Może też podpowiadać płynność związków między warstwami - ich przemieszczanie się i ruchliwość, a nie rozdzielność i statyczność.

Czwarta idea konstytutywna, ostatnia z wyróżnianych tutaj przeze mnie, uwypukla na tym tle istnienie czy też pojawianie się konfiguracji śladów: tych, które odsyłają w głąb i tych, które na powierzchni krystalizują się jako zwinięcia i skłębienia, zlepki i brekcje, konglomeraty, splątania koegzystujących fragmentów, okruchów i szczątków, tworzące mimo różnego pochodzenia i czasu powstania - kulturowo rozpoznawalne, typowe całostki. Josephine McDonagh akcentuje w związku z tym myśl, że palimpsest „stwarza tylko pozory głębi, w istocie bowiem funkcjonuje zawsze na poziomie powierzchniowym”3.

\section{Dwa tryby antropologicznej lektury palimpsestu: czytanie palimpsestyczne i czytanie palimpsestowe}

Przez analogię do czytania palimpsestu rozumianego dosłownie pojawia się teraz myśl o lekturze palimpsestu w sensie metaforycznym. Nie wypierając się podejścia tekstualistycznego, powie się więc, że miasto, wieś, krajobraz, dom gdzieś w mieście lub na wsi, mogą być metaforycznie ujmowane jako teksty nadające się do analizy i interpretacji, czyli często do - równie przenośnie pojmowanego - „czytania”.

Lektura takich palimpsestów odróżni w nich - nadające się do oddzielnej, ale i łącznej analizy i interpretacji - płaszczyzny: na przykład tę, która, gdy mowa o przestrzeni, jest traktowana jako jej aspekt fizyczny (materialny), i tę, którą opisuje się jako aspekt kulturowy, w tym etniczny. Często dla wygody, używając myślowego i językowego skrótu, mówi się dlatego o przestrzeni fizycznej (materialnej) i przestrzeni kulturowej (niematerialnej), a także o palimpseście fizycznym (materialnym) oraz palimpseście kulturowym (niematerialnym). Wszystkim tym określeniom nie przypisuje się zazwyczaj waloru ontologicznego, a jedynie epistemologiczny - są narzędziami analitycznymi

3 McDonagh 1987, s. 211; por. też przywołanie u Dillon 2005, s. 262, przypis 14. 
i niczym więcej: służą do „oglądania” i „czytania” palimpsestu od różnych stron, w różnych jego aspektach czy wymiarach.

Lektura palimpsestów przyjmie następnie - łącznie bądź rozdzielnie - jeden z dwóch trybów (ich rozróżnienie zawdzięczam Sarze Dillon): będzie czytaniem palimpsestycznym lub czytaniem palimpsestowym ${ }^{4}$. Dobrze jest w związku z tym uprzedzić, że wyrażenia „czytanie palimpsestyczne palimpsestów” (palimpsestic reading of palimpsests) i „czytanie palimpsestowe palimpsestów” (palimpsestuous reading of palimpsests) nie są niezdarnymi pleonazmami ${ }^{5}$. Czytanie palimpsestyczne to lektura tego, co materialne i niematerialne, a ułożone w nakładanych jedna na drugą warstwach, to zatem lektura sięgająca w głąb palimpsestu, nastawiona na ujawnianie tego, co - leżąc „poniżej” - nie mogło być dotąd rozpoznane jako „istotne” czy „ważne”. Czytanie palimpsestowe nie skupia się na tekście leżącym „poniżej”, nie chce go nawet studiować, by nie rozplątywać i nie niszczyć przez to palimpsestu ,istniejącego tylko i wyłącznie jako inwolucja tekstów"6. Powołując się na Michela Foucaulta, czytanie palimpsestyczne Sarah Dillon kojarzy z jego „archeologią”, czytanie zaś palimpsestowe z tym, co nazwał on „genealogią”. „Foucault dostrzega - pisze Dillon - że archeologia musi być łączona z genealogią [...]"7. O ile czytanie palimpsestyczne, związane z ,archeologią wiedzy” za swój cel obiera rezurekcję zapisu leżącego w głębi, u spodu - o ile zatem jest szukaniem śladów głębokich, a w nich odbicia historii i rozmaitych następujących po sobie, lecz i krzyżujących się dyskursów, o tyle czytanie palimpsestowe, podporządkowane "genealogii wiedzy", próbuje raczej śledzić to, co w powierzchniowej gmatwaninie lub powierzchniowym uporządkowaniu nieoczekiwanie scala lub radykalnie rozdziela pierwiastki kulturowo „zaszyfrowane”, w tym także jawnie ze sobą walczące - mimo przyległości, wypierające się siebie lub „tworzące związki tam, gdzie nie może albo nie powinno być żadnych”, to znaczy związki, wydawałoby się, kulturowo niedozwolone, zakazane ${ }^{8}$.

Oba tryby czytania palimpsestów - pozostające w tym ujęciu w przydatnej czy wręcz koniecznej symbiozie - mogą się jednak, jakby na przekór Foucaultowi, rozdzielać, a nawet odnosić do siebie krytycznie. W obrębie antropologii miasta tak właśnie reagują na siebie Monica Spiridon, opowiadająca się za czytaniem palimpsestycznym, to znaczy uwzględniającym wertykalny wymiar przestrzeni miasta, i Andreas Huyssen, chcący przede wszystkim - dzięki lekturze palimpsestowej - uchwycić jej wymiar horyzontalny ${ }^{9}$.

4 Dillon 2005, s. 244-245. Sarah Dillon, jak przed nią Josephine McDonagh, korzysta tutaj z wciąż inspirujących wielu badaczy dociekań dziewiętnastowiecznego klasyka Thomasa De Quincey.

5 Nie są nimi nawet, jak się okazuje, wyrażenia palimpsestic palimpsest i palimpsestuous palimpsest, por. de Groote 2014, s. 108-112.

6 Dillon 2005, s. 254.

Dillon 2005, s. 254.

Dillon 2005, s. 254.

9 Spiridon 2004, s. 1 oraz Spiridon 2006, s. 173-174; Huyssen 2003, s. 6-10, 72-84. 


\section{Tryby lektury a rodzaje praktyki etnograficznej}

Dwóm trybom lektury palimpsestów odpowiadają - jeśli się im przyjrzeć dokładniej - dwa rodzaje praktyki etnograficznej. Badanie palimpsestu - tak zapewne spojrzatby na nie Michel de Certeau - to wędrowanie, czy po prostu chodzenie po palimpseście ${ }^{10}$. Antropolog-etnograf chodzący po mieście lub po wsi, albo nawet tylko po domu tu lub tam, to obserwator i rozmówca - „kolekcjoner” wspomnień mieszkańców, zbieracz śladów w odsłoniętej głębi i śladów na czasem sprawiającej wrażenie galimatiasu, czasem skrzętnie uporządkowanej powierzchni, podążający za tajemnicą i zagadką, usiłujący odczytywać wzory, a więc kulturowo zaszyfrowane kompozycje śladów, pozostałości tego, co - poddane sprawczemu działaniu dyskursu, na przykład interetnicznego - kiedyś „było” lub jakoś wciąż „jest”, mimo że już nieobecne. Antropolog-etnograf, nazywany przez badaczy miasta, czasem na wyrost, flâneurem, kroczy, chwytając ślady, wpatrując się w nie i czując - zapewnia José Muñoz Millanes - jak i one „zdają się w niego wpatrywać"11. Ślady stają się dla niego etnograficznymi zaczepami: konkretami (takimi nawet jak pustka mówiąca o tym, że gdzieś coś było, albo milczenie, które przemawia niekiedy bardziej niż słowa) - konkretami unoszącymi ku antropologicznym interpretacjom. U José Muñoza Millanesa, badacza miasta, znalazłem wskazówkę, że badacz etnograf chodzący po przestrzeni wertykalnie to flâneur diachroniczny: „Miasto - pisze on samo przedstawia się [...] flâneurowi diachronicznemu jako ogromny archeologiczny depozyt, na którego wertykalnych przekrojach zjawiają się sceny, na nich zaś, w określony sposób, wciąż żyją wygasłe już żywoty i zdarzenia"12. Dodaję więc od siebie: miasto musi się fâneurowi synchronicznemu jawić jako genealogiczne splątanie, symultaniczność „sztywnych” i „ruchomych” tekstów, ich znaczeń raz jasnych, innym razem zaciemnionych, jako raz spokojna, innym razem pełna napięć - inwolucja. Wsparty przez Paula K. Saint-Amoura tłumaczę jeszcze jak on: flâneur diachroniczny to ktoś chodzący po osi „wertykalnej”, flâneur synchroniczny natomiast to wędrowiec posuwający się po osi „horyzontalnej”13. „Osie” są tu oczywiście odnoszone do wymiarów czy też wektorów palimpsestu, które stają się ścieżkami jego badawczej wędrówki.

Wyjście z miasta na wieś nic oprócz terminologii nie zmienia. Flâneur jest (czy też był) istotą miejską, etnograf - badacz przestrzeni miejskiej - flâneurem być może (na swój sposób) był i zapewne wciąż jest lub nadal chce być14. Antropologa-etnografa chodzącego po wsi, przy wszystkich podobieństwach, ale jednak z uwzględnieniem kluczowych różnic, musielibyśmy nazwać inaczej. Nie wiem jak, lecz czy to naprawdę ważne?

\footnotetext{
${ }^{10}$ de Certeau 2008, s. 93-110, 204-205.

${ }^{11}$ Muñoz Millanes 2000; por. Busà 2010.

${ }^{12}$ Muñoz Millanes 2000.

${ }^{13}$ Saint-Amour 2011; por. Lozier 2014.

${ }^{14}$ Do figury flâneura sam już wcześniej w swoich pracach nawiązywałem, por. Wejland 2010; Wejland 2017. Ale raczej nie mogłem lub nie chciałem być w nich badaczem-flâneurem, zwłaszcza w drugiej z nich, wybierając tam dla siebie kulturowy strój spacerowicza.
} 
Dla mojej własnej praktyki etnograficznej stanowczo ważniejsze jest coś innego: połączenie teraźniejszej penetracji wsi i domów na wsi z moją własną i moich rozmówców pamięcią, także tą o rysach autobiograficznych, po części również z tym, co - uwzględniając narracyjną naturę pamięci kulturowej - należy do „mówionej historii lokalnej”, do historii sąsiedzkiej wspólnoty relacjonowanej poprzez wspomnienia, poprzez osnute na oglądaniu albumów ze starymi zdjęciami opowiadanie o ludziach i zdarzeniach, którzy „tutaj” mieszkali, poprzez wspólne z nimi, „wspomnieniowe” (prawie jak u de Certeau w Paryżu) przechadzki po wsi.

\section{Dyskurs interetniczny: dom w przestrzeni nacechowanej etnicznie}

Każdy dom z biegiem czasu staje się palimpsestem - po bardziej lub mniej istotnych budowlanych przeróbkach, po nowej aranżacji pokoju gościnnego, po przemeblowaniu w kuchni, po zdarciu starej tapety lub przemalowaniu ścian w sypialni. Dom przekształcają zawsze w „piętrowy” palimpsest kolejne generacje i zupełnie nowi mieszkańcy. Wystarczy, że usuną po dawnych właścicielach lub lokatorach część nieswoich mebli i że wniosą swoje - obok wyglądających na antyki niewygodnych krzeseł postawią dopiero co kupione rozleniwiające fotele, że zdejmą znad drzwi jakiś „święty obrazek” i powieszą tam zupełnie inny, że część tego, co zastali po prostu usuną, zostawiając wolną przestrzeń.

Sytuacja szczególna, pobudzająca antropologa-etnografa do żywszej obserwacji, powstaje wtedy, gdy dom, któryś raz zasiedlany lub choćby tylko ponownie zamieszkiwany, znajduje się na kulturowym pograniczu, w „przestrzeni nacechowanej etnicznie”, jak określił ją (myśląc o mieście Łodzi) Mieczysław Dąbrowski - zwłaszcza w przestrzeni wsi polskiej i niepolskiej zarazem, mającej mieszaną etniczną tożsamość ${ }^{15}$. Sam dom, do którego w pewnym czasie wprowadzają się Polacy, może okazać się na przykład domem poniemieckim. Jego charakter jako palimpsestu zostanie wzmocniony świadomością różnicy etnicznej: tkwiącej już w tym, co jest jego materią i w tym, co składa się na jego sens niematerialny. Czy przywołujący historię dyskurs interetniczny da zatem impuls do tego, by zamieszkując taki dom, wykluczyć od razu swoje w nim zadomowienie, czy też - na odwrót - znaleźć sposób na uczynienie go w jakimś codziennym sensie domem „swoim”?

\section{Dwa poniemieckie domy-palimpsesty w Cekcynie i ich loci}

Oto dwa poniemieckie domy w Cekcynie - wsi w Borach Tucholskich, naznaczonej wiele razy w dziejach długotrwałą obecnością Niemców - przykład zapewne etnograficznie typowy dla tutejszej okolicy. Stoją po sąsiedzku, prawie naprzeciwko, po dwóch stronach niezbyt ważnej drogi, w bok od Lubińska, wsi z tradycją protestancką. Zewnętrznie podobne do siebie, murowane, „z niemieckiej, czerwonej cegły”, parterowe,

${ }^{15}$ Dąbrowski 2001, s. 88-90. 
ze strychem pod dwuspadowym dachem. Do dziś o każdym z nich mówią tu ehemals deutsches Haus, bo przez Niemców zostały wybudowane i przez lata wojny utrzymywane w „niemieckim porządku”. Przejęte po Niemcach jeszcze za ich bytności tutaj lub tuż przed ich wyjazdem czy też wysiedleniem w latach 1945-1947, niezniszczone, w dobrym stanie, $z$ zadbanym obejściem, przylegającym ogrodem i kawałkiem ziemi pod uprawę ${ }^{16}$.

Niemieccy mieszkańcy pierwszego domu nosili nazwisko Patyga, ci zaś, co zamieszkali w nim po wojnie, to Pietrusewiczowie, przybysze zza Buga. Dotarli tutaj z pewną wymuszoną zwłoką, wysiedleni ze swoich rodzinnych stron - z wyraźną dyrektywą tak zwanej repatriacji właśnie do Cekcyna, pod Lubińsk.

Niemieccy właściciele drugiego domu to Weltrowie, ci natomiast, co po nich nastali, to Porożyńscy - on Borowiak, prawie tutejszy, bo z niedalekich Budzisk, ona „dama z Łodzi”. Dom „po Niemcach” - ten właśnie, a nie inny, sami wypatrzyli i w urzędzie sobie ,załatwili”.

Cofając się pamięcią i opowieściami do tamtych czasów, przejdźmy się teraz po obu domach, potwierdzając, że dzięki intencjom i działaniom Pietrusewiczów oraz Porożyńskich stały się one palimpsestami etnicznymi. Poszukajmy jednocześnie w ich palimpsestowym wnętrzu charakterystycznych loci - kompozycji śladów-rzeczy, czyli układów osobliwie niezadomawiających bądź zadomawiających ${ }^{17}$. Locus każdego domu to jego sens jako miejsca - poddany dyskursowi interetnicznemu, „wpisany” w przestrzeń wsi przez kulturową pamięć i wspólnotowe narracje historyczne ${ }^{18}$.

W obu domach, w chwili gdy zajmowali je Pietrusewiczowie i Porożyńscy, były jeszcze rozmaite niemieckie sprzęty i rzeczy, choćby lampy naftowe stojące i do powieszenia na ścianie, wysokie piece kaflowe $z$ wyrytymi na drzwiczkach niemieckimi napisami, ogromne łóżka i masywne stoły. Pietrusewiczowie od razu wzięli się do malowania ścian, Porożyńscy - bez pośpiechu, dopiero za jakiś czas, ponieważ ściany „ich” domu nie były, jak twierdzili, ani brudne, ani brzydkie. Patygowie i Weltrowie starali się co prawda

${ }^{16}$ Oba domy znajdowały się wtedy w obrębie wsi Cekcyn. W wyniku późniejszych przekształceń terytorialnych zostały - wraz z najbliższą okolicą - przyłączone do wsi (kolonii) Lubińsk. Antropologia uprawiana historycznie uwzględnia wprawdzie te przemiany administracyjne, nie może jednak przeoczyć faktu, że „mówiona historia lokalna” rozsądnie miesza czasy - raz oba domy przypisując do Cekcyna, a raz do Lubińska.

${ }^{17}$ Potrzebę analizy kompozycji (ciągów i łańcuchów) śladów-rzeczy uwypukla Jon Anderson (Anderson 2010, s. 1-12, 37-52), por. też Napolitano 2015. Na moje myślenie o śladach i śladach-rzeczach istotnie wpłynęły również znakomite - mądre i piękne - szkice filozoficzne Barbary Skargi, w jednym z fragmentów poświęcone śladowi-bliźnie, jaki pozostawia utrata domu, wygnanie i prześladowanie (Skarga 2002, s. 92-95).

${ }^{18}$ U początków takiego rozumienia przeze mnie słowa locus leży koncepcja Paula Connertona, dla którego locus to miejsce pamięci kulturowej (site of cultural memory), takie zwłaszcza jak dom rodzinny, ale także ulica (Connerton 2009, s. 18-22; por też Connerton 2003, s. 5; Czajkowska 2016). Od Connertona jednak - przesuwając akcent $\mathrm{z}$ miejsca na jego sens - świadomie odbiegam. 
zabrać ze sobą do Niemiec rzeczy osobiste, ale trochę ich z różnych powodów, w tym przez nieuwagę lub pośpiech, zostawili. Pietrusewiczowie wyrzucali je na śmieci i palili. Porożyńscy po części zostawiali - na przykład rodzinne niemieckie dokumenty i fotografie - w osobnym drewnianym pudle, wynoszonym na strych. Do swoich zbiorów „pamiątek poniemieckich” przekładali zaś choćby popularne wówczas mechaniczne wycinanki „cienie”.

\section{Dom Pietrusewiczów i locus niezadomowienia}

Locus domu Pietrusewiczów to locus niezadomowienia. Gdy się po nim okiem antropologa-etnografa rozejrzeć, gdy go przejść w poszukiwaniu szczególnych układów rzeczy-śladów, okaże się od razu, że rzeczy jest tu niewiele, a cała przestrzeń wewnętrzna jest uporządkowana wedle zasady „obce - swoje”. Rzeczy zastane, jeśli nie zostały wyrzucone, i ściany słyszą nieustanne wypominanie, że są rzeczami i murami niemieckimi. Od nielicznych rzeczy przywiezionych „stamtąd”, „z domu” lub otrzymanych od polskich sąsiadów zaraz po przybyciu, oddziela je pusta podłoga $z$ drewnianych desek i dosadny (widoczny choćby w gestach) dystans mentalny. Rzeczy „stamtąd” są jakby „wycięte" z dawnego rodzinnego domu i wciąż go przywołują w codziennych rozmowach. Są zresztą określane „po swojemu” - ich nazwy to w większości nazwy przywiezione. Pietrusewiczowie z rzadka używają nazw „stąd”, nawet tych borowiackich. Przestrzeń wewnątrz domu pozostaje we fragmentach nawet nienazwana, a zatem jakby niepojęta. Język Pietrusewiczów wypełniony jest za to wyrażeniami wskazującymi: „to”, „tego”, „to to" i „tamto”, dopełnianymi w codziennej komunikacji przez konkretyzujące gesty albo rozumianymi - jak to w zwartej wspólnocie dyskursu - i bez nich. Wszystkie rzeczy są zresztą w ich nowym domu nie na swoim miejscu: te przywiezione powinny być „tam”, a tych niemieckich nie powinno być „tutaj” wcale.

Wnętrze domu Pietrusewiczów nie zna, jak widać, etnicznych zagmatwań czy etnicznych "niedopuszczalnych” skojarzeń - jego locus wyraża radykalne interetniczne rozdzielenie. Kwintesencją tej kulturowej kompozycji rzeczy-śladów jest pokój gościnny - nieprzytulny, jak wspominają do dziś sąsiedzi, po prostu „niegościnny”, mimo gościnności samych Pietrusewiczów. Może przez to, że pustawy, z dwiema ciężkimi ławami pod ścianami i prostym, podłużnym (jednak poniemieckim) stołem. Na ścianie po oknem - oprawiony w drewnianą ramę - obraz Matki Boskiej (jeśli pamięć nie zawodzi - tej z Ostrej Bramy), na parapecie okiennym jakiś inny święty obrazek, a obok zaczytana książeczka do nabożeństwa, albo i dwie książeczki, „stamtąd”. Żadnych rodzinnych zdjęć na widoku, z wyjątkiem tych wśród kart modlitewników i w schowanych $\mathrm{w}$ papierowej teczce dokumentach.

Czytanie palimpsestowe tego domu - nawet nieangażujące zbytnio czytania palimpsestycznego - wystarcza do stwierdzenia, że locus niezadomowienia przenika w nim wszystko. Sami Pietrusewiczowie w rozmowach nie ukrywają zresztą tego, że czują się tu nie tak jak u siebie, że do opuszczenia domu „tam” zostali zmuszeni przez „Ruskich”, 
lecz on wciąż tkwi w ich sercach. Losowi mają za złe, że przyszło im mieszkać w domu niemieckim. Mówią im co prawda w urzędzie, że to teraz ich dom, ale oni ciągle odczuwają niepewność, a przede wszystkim mają nadzieję na jego opuszczenie. Locus niezadomowienia, oparty na stanowczym odcinaniu się od tego, co niemieckie, z ostentacyjnym podkreślaniem polskiej tożsamości (również wobec polskich sąsiadów), znajduje więc potwierdzenie w poczuciu tymczasowości i prowizoryczności. Dom „tutaj” nie mógł być dla Pietrusewiczów - jak może był gdzie indziej dla innych - „miejscem przesuniętym” (by użyć nazwy stosowanej przez Małgorzatę Czermińską) ${ }^{19}$. Było to dla nich raczej „miejsce przechodnie” - takie, w którym jest się do czasu, do wyczekiwanej chwili przejścia dalej, najlepiej w przestrzeń „swoją”. Być może udało się to Pietrusewiczom dopiero po jakichś pięciu czy sześciu latach, gdy sprzedali dom i całe gospodarstwo Kameckim i wyjechali do rodziny do Gdańska. „Tutaj” rodziny nie mieli, ani tym bardziej nie przyjechali „całą wsią”. Razem z nimi przybył „stamtąd” tylko Józek, kolega młodego Pietrusewicza - Janka jąkały.

\section{Dom Porożyńskich i locus zadomowienia}

Locus domu Porożyńskich to locus zadomowienia. Z lektury powierzchni tego etnicznego palimpsestu wynika, że ślady-rzeczy układają się w nim zgodnie z regułą przystosowania do tego, co poniemieckie. Przygarniane są rzeczy jakościowo dobre lub „ładne”. Co prawda rzeczy po Niemcach nie zmieniają metryki i pozostają rzeczami „poniemieckimi”, ale - już dzięki samemu temu przygarnięciu - są przez Porożyńskich jakby adoptowane do polskości. Nie noszą stygmatu „złej niemieckości”, przeciwnie niektóre zwłaszcza są uważane za „po niemiecku solidne”. Porożyńscy przybyli tutaj po robotach w Niemczech, lecz podkreślanie własnej etnicznej tożsamości nie przeszkadzało im mówić z szacunkiem o „dobrych niemieckich bauerach”. Niemcy nie byli przyjaciółmi - Porożyński walczył z nimi jako żołnierz, tyle że większymi ich wrogami - jak dla Pietrusewiczów - okazali się „Ruscy”, zwykle nazywani przez jednych i drugich mniej oględnie.

Do rzeczy poniemieckich, nazywanych niekiedy wprost po niemiecku, zostały dodane rzeczy przywiezione (część najpierw na rowerze) od matki i siostry Porożyńskiego z rodzinnych Budzisk. Miały nazwy zazwyczaj podwójne - on określał je chętnie po borowiacku, ona „po łódzku”. Pokój gościnny - kwintesencja zupełnie innej kompozycji rzeczy-śladów - nie wykazywał etnicznego rozdzielenia, wprowadzał za to niekiedy zaskakujące, zdawałoby się kulturowo „niedopuszczalne” i „zakazane” połączenia. Na szerokim parapecie okna wychodzącego na podwórze stał krzyż „przeciwburzowy”, a obok niego - w ozdobnej ramce - obrazek Matki Boskiej Częstochowskiej, niedaleko zaś leżała polska książeczka z nowenną i koronką do Miłosierdzia Bożego, z wciśniętym między kartki, chyba otrzymanym od Weltrów, obrazkiem Jesus, ich vertraue aufDich. Stojący

${ }^{19}$ Czermińska 2011, s. 195-197. 
na środku pokoju duży, dębowy stół był stołem poniemieckim, podobnie jak ulokowana pod ścianą maszyna do szycia - taka z nożnym napędem - raczej gritzner niż singer (co sugeruje zupełnie współczesne znalezisko - maszyny marki Gritzner właśnie - na strychu nowego, później nieopodal wybudowanego domu Porożyńskich). Na ścianie nad wąską kanapą umieścili oni w pokoju gościnnym swoją sporej wielkości, podretuszowaną fotografię ślubną. Na ścianie $\mathrm{z}$ wejściem do sypialni wisiał natomiast, połyskujący drewnianą, ciemnobrązową skrzynką, poniemiecki zegar - $\mathrm{z}$ wahadłem w kształcie serca, z łańcuszkami, nakręcany ręcznie kluczykiem, głębokim dźwiękiem wybijający godziny i kwadranse. Junghans albo Gustav Becker - z pamięci trudno wydobyć ten szczegół. Ozdobny dywan zajmował prawie całą podłogę; Porożyńscy mówili, że to dywan „perski”, chociaż poniemiecki.

Czytanie palimpsestowe domu Porożyńskich ujawnia prosty wzór śladów-rzeczy: kombinację zadomowienia pośród tego, co z pochodzenia było niemieckie, i tego, co od zawsze było polskie. Ślady-rzeczy, w swojej wielości i rozmaitości (ale nie nieporządku) nie manifestują tutaj poczucia obcości, przeciwnie - objawiają (prawie pełne) „bycie u siebie”, „na swoim”, i to do tego stopnia, że można się domem cieszyć, a nawet (gdy ktoś, na przykład z Łodzi, przybywa w gościnę) po prostu się nim szczycić.

Dlaczego „prawie pełne”, nie zaś całkowite, było zadomowienie Porożyńskich w poniemieckim domu? Ponieważ on marzył jednak o domu „naprawdę własnym”. A gdy się to po latach udało, oddał „swój” stary dom w ręce Bucholców, dziś Kulczyków²0.

\section{Domy-palimpsesty etniczne i wiejskie „długie trwanie”}

Charakter każdego z obu poniemieckich domów - jak i całej wiejskiej cekcyńskiej okolicy - jako palimpsestu etnicznego utrzymuje się do dziś. Lokalna historia jest tutaj stale aktywna. Pamięć dawnych dziejów skrzętnie jest przechowywana, a opowieści o nich są snute przy różnych okazjach. Zewnętrznie domy zachowały swój dawny kształt, obejścia wokół nich są prawie takie jak kiedyś, nawet furtki prowadzące z drogi na podwórze są w tym samym miejscu ${ }^{21}$.

W zadziwiający sposób domy te powtarzają też starą różnicę, jakby więc tkwią w wiejskim „długim trwaniu”. Przejście się po czy raczej wokół domu Pietrusewiczów, potem Kameckich, odsłania niezwykłą pustkę i porażającą ciszę. Dom został opuszczony przez „młodego Kameckiego” - ścigany z powodu długów uciekł on ponoć do

\footnotetext{
${ }^{20}$ Locus niezadomowienia u Pietrusewiczów i locus zadomowienia u Porożyńskich to sporej części wytwór pamięci „wpisanej” w dom poniemiecki. Użycie rozróżnienia zaproponowanego (na zupełnie inną wprawdzie okazję) przez Michaela Rothberga pozwala dostrzec, że pamięć, która nie zadomawia, jest pamięcią konkurującą, odrzucającą i konfliktową, podczas gdy pamięć, która zadomawia, to pamięć wielokierunkowa, wchłaniająca i koegzystująca (Rothberg 2009, s. 1-12; por. Rothberg 2011).

${ }^{21}$ Mój ostatni pobyt w Cekcynie - sentymentalny powrót po latach i zarazem najprawdziwsza badawcza ekspedycja - przypadł na początek i środek września 2017 roku. Cekcyn z mojej autobiograficznej pamięci, wzbogaconej o nabytą dużo później wiedzę etnograficzną, przedstawiłem w artykule Wejland 2014.
} 
Niemiec, nad całym domostwem nadzór objął więc komornik. Psia buda, jak dom, też tu pusta, bez lokatorów. Zajść do domu Porożyńskich, obecnie Kulczyków, to od razu natknąć się na biegającego po podwórzu, niesiedzącego w budzie Gucia, a potem trafić do zadbanego, nowocześnie, choć skromnie wyposażonego, pełnego życia domu.

Antropologiczna lektura obu domów-palimpsestów jest wciąż możliwa. Przestrzeń wsi cekcyńskiej, a zwłaszcza etnograficznie przeze mnie penetrowanych wybudowań pod Lubińsk, nie utraciła swoich własności. To ciągle „przestrzeń nacechowana etnicznie", jak kiedyś, tak i dziś przez przybyszów zamieszkiwana i - być może - szczęśliwie albo bez powodzenia zadomawiana ${ }^{22}$.

\section{Bibliografia}

Anderson J. 2010, Understanding Cultural Geography. Places and Traces, Routledge, London and New York.

Bagłajewski A. 1999, Miasto-palimpsest, [w:] Miejsce rzerzywiste, miejsce wyobrażone. Studia nad kategoriq miejsca, Kitowska-Łysiak M., Wolicka E. (red.), Towarzystwo Naukowe KUL, Lublin 1999, s. 317-338.

Błażejewski T. 2007, Podróż do enklawy czasu, „Acta Universitatis Lodziensis, Folia Litteraria Polonica" tom 9, s. 149-155.

Burzyńska A.R. 2013, Watbrzych. Miasto jako palimpsest, „Slovenské Divadlo” tom 61, nr 4, s. $400-406$.

Busà A 2010, City of Memory, [w:] Hutchison R. (ed.), Encyclopedia of Urban Studies, Sage, Los Angeles - London, s. 158-161.

de Certeau M.2008, Wynaleźćcodzienność. Sztuki dziatania, przeł.Thiel-Jańczuk K., Wydawnictwo Uniwersytetu Jagiellońskiego, Kraków.

Connerton P. 2003, Memory and the body's topography, "Journal of Romance Studies" vol. 3 no. 1, s. $5-16$.

Connerton P. 2009, How Modernity Forgets, Cambridge University Press, Cambridge - New York.

${ }^{22}$ Wszystkim moim rozmówcom w Cekcynie-Lubińsku przy tej okazji serdecznie dziękuję za niegasnącą ochotę do wspomnień. Dziękuję zwłaszcza pani Teresie z domu Bucholc Kulczykowej za długie godziny rozmów o dawnych czasach i ich domu, oraz o domu po sąsiedzku, jej mężowi zaś, panu Stanisławowi, za piękną retrospekcję o baśce, grze w karty w sobotnie i niedzielne popołudnia u Porożyńskich. Osobno dziękuję pani Marii Berendt, dzięki której pełen starych rzeczy strych nowego domu Porożyńskich mogłem przeszukać i która na leciwego gritznera, maszynę do szycia, sama mnie tam naprowadziła. Za wcale nieprzypadkowe rozmowy o obu domach i ich mieszkańcach, zwłaszcza o „Bronichu” Porożyńskim, wypada mi też podziękować państwu Ilonie i Andrzejowi Ziółkowskim. Wdzięczny jestem ponadto innym, chętnie wędrującym wraz ze mną po wsi (choćby tylko w swoich opowieściach), mieszkańcom Cekcyna-Lubińska. 
Czabanowska-Wróbel A. 2011, Palimpsest Krakowa zprzetomu XIX i XX wieku-ślady przesztości $i$ znaki tego, co nowe, [w:] Kraków i Galicja wobec przemian cywilizacyjnych 1866-1914. Studia i szkice, Fiołek K., Stala M. (red.), Universitas, Kraków, s. 345-362.

Czabanowska-Wróbel A. 2013, Palimpsest Krakowa z przetomu XIX i XX wieku-ślady przesztości i znaki tego, co nowe, [w:] Czabanowska-Wróbel A., Sprzeczne żywioty. Mtoda Polska i okolice, Wydawnictwo Uniwersytetu Jagiellońskiego, Kraków, s. 215-230.

Czajkowska A. 2016, Miejsce i pamięć. W poszukiwaniu przestanek badań biograficznych, „Teraźniejszość - Człowiek - Edukacja” tom 19, numer 4(76), s. 23-44.

Czermińska M. 2011, Miejsca autobiograficzne. Propozycja w ramach geopoetyki, „Teksty Drugie” nr 5, s. 183-200.

Czermińska M. 2013, Tożsamość ksztattowana w pamięci miejsca, „Ruch Literacki” rok LIV, zeszyt 6 (321), s. 591-606.

Dąbrowski M. 2001, Swój/obcy/inny. Z problemów interferencji i komunikacji kulturowej, Świat Literacki, Izabelin.

Dillon S. 2005, Reinscribing De Quincey's palimpsest: the significance of the palimpsest in contemporary literary and cultural studies, "Textual Practice” vol. 19 no. 3, s. 243-263.

Golonka-Czajkowska M. 2017, Dziedzictwo jako scena rytualna. Przypadek Starego Miasta w Krakowie, „Zeszyty Naukowe Uniwersytetu Jagiellońskiego. Prace Etnograficzne”, tom 45, z. 3, s. 299-314.

Gomóła A, Szawerna-Dyrszka A. (red.) 2018, Palimpsest. Miejsca i przestrzenie, Wydawnictwo Uniwersytetu Śląskiego, Katowice.

de Groote B. 2014, The Palimpsest as a Double Structure of Memory. The Rhetoric of Time, Memory and Origins in Thomas De Quincey and Thomas Carlyle, "Orbis Litterarum" vol. 69 issue 2, s. 108-133.

Huyssen A. 2003, Present Pasts. Urban Palimpsests and the Politics of Memory, Stanford University Press, Stanford, California.

Karpińska G.E. 2004a, Miasto wymazywane. Historia tódzkiego przypadku, „Studia Etnologiczne i Antropologiczne" nr 8, 165-178.

Karpińska G.E. 2004b, Palimpsestowe oblicze miasta. Przyktad Eodzi przemystowej, „Ochrona Zabytków" nr 3-4, s. 127-140.

Karpińska G.E 2015, Zdobne fasady, smętne palimpsesty. Nie tylko o wygladzie tódzkich osiedli robotniczych, „Journal of Urban Ethnology” tom 13, s. 39-51.

Kasner M. 2017, O metodologii badań kultury pamięci miasta postsocjalistycznego (na przyktadzie wspótczesnego Wilna), „Slavistica Vilnensis” nr 62, s. 277-290.

Kowerko-Urbańczyk M. 2013, Wilno jako projekt nienostalgiczny. Litewska proza wobec wielokulturowości i palimpsestowości Wilna, „Porównania” vol. 12, s. 87-102.

Kuchowicz K., Wolak A.M. 2012, Wspomnienie miasta. Rola pamięci w wybranych utworach Orhana Pamuka, „Bez Porównania. Czasopismo naukowe studentów komparatystyki UJ” nr 1 (11), s. 31-52. 
Lozier C. 2014, Writing the city: London as urban palimpsest in Louis Ferdinand Céline's Guignol's Band I \& II, "Journal of Romance Studies" vol. 14 issue 3, s. 23-36.

Lul M.2011, Literackie fizjonomie Wilna czasów Kraszerwskiego z Litwa w tle. Przegla d problematyki w świetle najnowszego stanu badan, „Białostockie Studia Literaturoznawcze” nr 2, s. 135-145. McDonagh J.1987, Writings on the Mind: Thomas De Quincey and the Importance of the Palimpsest in Nineteenth Century Thought, "Prose Studies" vol. 10 issue 2, s. 207-224.

Muñoz Millanes J. 2000, The City as Palimpsest, Lehman College \& Graduate Center, City Univeristy of New York, http://www.lehman.cuny.edu/ciberletras/v03/Munoz.html (dostęp: 12.02.2015).

Napolitano V. 2015, Anthropology and traces, "Anthropological Theory" vol. 15 issue 1, s. 47-67.

Rewers E. 2005, Post-polis. Wstęp do filozofii ponowoczesnego miasta, Universitas, Kraków.

Rogóż L. 2015, Dzieciństwo po Jatcie - poetyka i aksjologia w kontekście polskiej literatury wspótczesnej, Uniwersytet Rzeszowski, Rzeszów. Rozprawa doktorska, https://repozytorium.ur.edu. pl/bitstream/handle/item/1283/ROZPRAWA\%20DOKTORSKA\%20DZIECIŃSTW O\%20PO\%20JAŁCIE\%20LUCYNA\%20ROGÓŻ.pdf?sequence=1 (dostęp: 30.3.2019).

Rothberg M.2009, Multidirectional Memory. Remembering the Holocaust in the Age of Decolonization, Stanford University Press, Stanford, California.

Rothberg M. 2011, From Gaza to Warsaw. Mapping Multidirectional Memory, "Criticism" vol. 53, no. 4 , s. 523-548.

Rybicka E. 2011, Pamięć i miasto. Palimpsest vs. pole walki, „Teksty Drugie” nr 5, s. 201-211.

Saint-Amour P.K. 2011, The Vertical Flâneur: Narratorial Tradecraft in the Colonial Metropolis, [w:] Duffy E., Boscagli M. (ed.), Joyce, Benjamin, and Magical Urbanism: European Joyce Studies 21, Rodopi, Amsterdam, s. 224-249.

Skarga B. 2002, Ślad i obecność, Wydawnictwo Naukowe PWN, Warszawa.

Spiridon M. 2004, How to make sense of space: The Capital-City of Byzantium, ACUME European Thematic Network, Cultures of Memory/Memories of Culture, International Conference, Cyprus, 20-22 February 2004, http://www2.lingue.unibo.it/acume/agenda/cyprus/papers/p_spiridon.htm (dostęp: 19.11.2018).

Spiridon M. 2006, The City of Texts, [w:] Ascari M., Corrado A. (ed.), Sites of Exchange: European Crossroads and Faultlines, Rodopi, Amsterdam - New York NY, s. 169-176.

Szalewska K. 2017, Urbanalia - miasto i jego teksty. Humanistyczne studia miejskie, Fundacja Terytoria Książki, Gdańsk.

Taranek-Wolańska O. 2013, Stacja Watbrzych, czyli transgranicznośc i doświadczanie miejsca, [w:] Ursel M.,Taranek-Wolańska O.(red.), Ślaskie pogranicza kultur, tom 2, Oficyna Wydawnicza ATUT, Wrocław, s. 145-158.

Usakiewicz K. 2012, Ptowdiw jako miasto-palimpsest. Próba analizy porównawczej, „Studenckie Zeszyty Naukowe Instytutu Filologii Słowiańskiej UJ” nr 2, s. 85-99.

Wejland A.P. 2010, Latem w parku. Epifanie codzienności, [w:] Godula-Węcławowicz R. (red.), Lato w mieście. Różne oblicza kultury, Instytut Archeologii i Etnologii PAN, Kraków Warszawa, s. 145-162. 
Wejland A.P. 2013, O definiowaniu w humanistyce - między retorykq a etyka, [w:] Kasprzyk D. (red.), Nie tylko o wsi... Szkice humanistyczne dedykowane Profesor Marii Wieruszerwskiej-Adamczyk, Wydawnictwo Uniwersytetu Łódzkiego, Łódź, s. 197-225.

Wejland A.P. 2014, Mój Cekcyn. Fragmenty autobiograficzne, „Zeszyty Wiejskie” z. XIX, s. 69-85.

Wejland A.P. 2017, Zimq w parku. O kontemplacji antropologicznej, „Journal of Urban Ethnology” t. 15 , s. $115-127$.

Weżgowiec B. 2013, Miasto i pisarz. Gdańsk i jego historia w prozie Stefana Chwina, Uniwersytet Warszawski, Wydział „Artes Liberales”, Warszawa. Rozprawa doktorska, https://depotuw. ceon.pl/bitstream/handle/item/675/BARBARA\%20WEZGOWIEC\%20DOKTORAT. pdf?sequence=1 (dostęp: 25.01.2018).

Wójcik-Żołądek M. 2014, Od Königsberga do Kaliningradu. Nazwy miast jako miejsca pamięci, „Przegląd Zachodni” nr 2(351), s. 254-273. 
